\title{
Usability, customer satisfaction, service, and trust towards mobile banking user loyalty
}

\author{
Victoria Detra Johannes, Indarini, \& Silvia Margaretha \\ University of Surabaya, Surabaya, Indonesia
}

\begin{abstract}
The purpose of this research is to analyze the influence of usability, customer satisfaction, customer service and trust towards mobile banking user loyalty in Surabaya. The data used in this research were primary data obtained from questionnaires. Respondents of the study were 200 respondents who live in Surabaya and use mobile banking facility from BCA, BNI or Bank Mandiri over the past 6 months. Data processing was conducted using SPSS 18 for Windows and Amos Graphic 21 for Windows. Non-probability sampling with purposive sampling type was applied as the sampling technique. The result of this research showed there is a positive influence between usability, customer satisfaction, customer service and trust towards loyalty.

Keywords: trust, customer satisfaction, customer service, trust, loyalty, mobile banking
\end{abstract}

\section{INTRODUCTION}

Technological advancements tighten the competition in the globalization era. Various information can be accessed anytime and anywhere via the internet. A variety of needs and transactions that used to be done only manually can now be done digitally even from home without the need for face-to-face interaction or going to a service provider. In order to deal with these technological advancements, a company should utilize the information technology in order to reach more consumers and meet the needs and demands without time and space constraints.

One of the rapid growing services with increasing users and transaction is mobile banking. According to investopedia.com, mobile banking is defined as "the use of a smart phone or other mobile devices to perform online banking tasks while away from your home computer, such as monitoring account balances, transferring funds between accounts, bill payments and locating an ATM".

There is no significant difference between internet banking and mobile banking. Mobile banking uses applications provided by banks through platforms or media such as iOS and Android. Meanwhile, internet banking is generally still accessible through a particular website address with multiple securities and usually accompanied by a companion tool or device that is the key used for transaction.
Yet, internet banking can also be accessed via mobile phone or tablet computer.

This research was conducted to examine the influence of usability, customer satisfaction, customer service, and trust to mobile banking user loyalty in Surabaya. Based on several previous studies examined, there is a research gap related to the influence of trust towards loyalty.

Thakur (2014) shows trust does not significantly affect the loyalty of mobile banking users. While previous studies (Mukherjee \& Nath 2003, Schaupp \& Belanger 2005) show the contrary result. Moreover, some researches in Indonesia by Maharsi \& Fenny (2006) demonstrate that trust and sense of security affect customer loyalty.

\section{LITERATURE REVIEW}

The effect of usability on customer satisfaction Thakur (2014) states that "Ease of use or usability is one of the most important factors for determining the quality of a web site and therefore, it influences the levels of customer satisfaction". H1: Usability has a direct and positive effect on satisfaction in $\mathrm{m}$-banking business.

The effect of customer service on customer satisfaction Thakur (2014) stated in his research "customer service affects customer satisfaction positively and significantly. H2: Customer service has a direct 
banking business.

The effect of usability on customer service, Takhur (2014) argues that a good interface display and ease of use will make customers feel positive about customer service. If the consumer is provided with information on how to use the application, the customer will likely have a positive evaluation of the service.

Based on research conducted by Floh \& Treiblmaier (2006), "Usability has been found to be an antecedent of customer service". H3: Usability has a direct and positive effect on customer service on $\mathrm{m}$ banking business.

The effect of customer service to trust, based on a study conducted by Zhou (2012) usability has a significant effect on trust. While Yeh \& Li (2009) whose research was conducted in Taiwan stated that, "Unlike previous the results indicated that interactivity and responsiveness did not lead to trust development." Thus, the positive influence of usability and customer service on trusts should be investigated". $\mathrm{H} 4$ : Customer service has a direct and positive impact on customer trust in m-banking business.

The effect of usability to trust, based on a study on the adoption of m-banking users in four areas conducted by Zhou (2012) in China stated that, "Besides structural assurance, both ubiquity and perceived ease of use have significant effects on trust." There fore ease of use or usability have a significant influence on trust, and refers to the results of research Darmasetiawan et al. (2013) that trust underlay cooperation between one another. H5: Usability has a direct and positive effect on customer trust in m-banking business.

The effect of customer satisfaction on loyalty Thakur (2014) has proposed that the intention to continue to use a service is influenced by the satisfaction of the online application itself. In accordance with the existing literature that users who are not satisfied with the services of a company will seek satisfaction elsewhere (O'Malley \& Tynan 2000, Lin \& Wang 2006). Other marketing literature also states that the higher the level of satisfaction will tend to increase one's loyalty level (Anderson 1994, Gangguli \& Roy 2011, Hallowell 1996, Yoon \& Kim 2000). H6: Customer satisfaction has a direct and positive impact on customer loyalty in m-banking business.

The effect of trust on loyalty in addition to customer satisfaction, a study conducted by Lin \& Wang (2006) mentions that trust has an influence on customer loyalty. Reducing the risk of online transactions and maintaining transaction trusts are key to attracting and retaining customers (Lee \& Chung 2009, Luo et al. 2010). H7: Customer trust has a direct and positive impact on customer loyalty in m-banking business.
This research uses primary data and information. The data obtained through questionnaire distribution to the respondents with specified targets and characteristics. This questionnaire contains a list of written statements about the responses of respondents to the usability, customer satisfaction, trust, customer service and loyalty of mobile banking users of Bank BCA, Bank BNI and Bank Mandiri.

The target population of this study is customers who registered and used mobile banking facilities over the past 6 months. The characteristics of the population are: (1) customers registering and using mobile banking facilities from Bank BCA, Bank BNI or Bank Mandiri over the past 6 months; (2) Aged over 19 years; (3) having minimum education level of Senior High School/Vocational School; and (4) domiciled in Surabaya. These respondents are expected to provide the required information which match with the research purposes. The measurement scale of this study uses interval measurement scale with a numerical scale of 1 to 7 .

\section{RESULT AND DISCUSSION}

Using the questionnaire distribution, data processing will be done to obtain the result of hypothesis proof. Measurement model result shows that each indicator has standardized loadings $>0.5$ and generated AVE is $>0.5$ which demonstrate that indicator of all research variables namely usability, customer service, customer satisfaction, trust, and loyalty have shown good measurements. Construct reliability values generated in each variable is $>0.7$ which indicates that these indicators have good reliability. Amos software was used to test the measurement and structural model which then followed by hypothesis analysis that explains the acceptance or rejection of a hypothesis. The result can be seen in table 1:

Table 1. Analysis of the coefficient of determination of a multiple linear regression.

\begin{tabular}{llll}
\hline & Hypothesis & C.R. & Description \\
\hline H1 & $\begin{array}{l}\text { Usability } \rightarrow \\
\text { Satisfaction }\end{array}$ & $2.27 * * *$ & supported \\
H2 & $\begin{array}{l}\text { Customer Service } \rightarrow \\
\text { Satisfaction }\end{array}$ & $3.86^{* * *}$ & supported \\
H3 $\begin{array}{l}\text { Usability } \rightarrow \\
\text { Customer Service }\end{array}$ & $11.70 * * *$ & supported \\
H4 $\begin{array}{l}\text { Customer Service } \rightarrow \\
\text { Trust }\end{array}$ & $4.69 * * *$ & supported \\
H5 & $\begin{array}{l}\text { Usability } \rightarrow \text { Trust } \\
\text { H6 }\end{array}$ & $\begin{array}{l}\text { Satisfaction } \rightarrow \\
\text { Loyalty }\end{array}$ & $2.11 * * *$ \\
H7 & $\begin{array}{l}\text { Trust } \rightarrow \text { Loyalty } \\
* * *\end{array}$ & $\begin{array}{l}8.02 * * * \\
\text { significant as p-value }<0.1 \% \text { or } 0.001 .\end{array}$ & supported \\
Based on the result of hypothesis testing, it can be
\end{tabular}




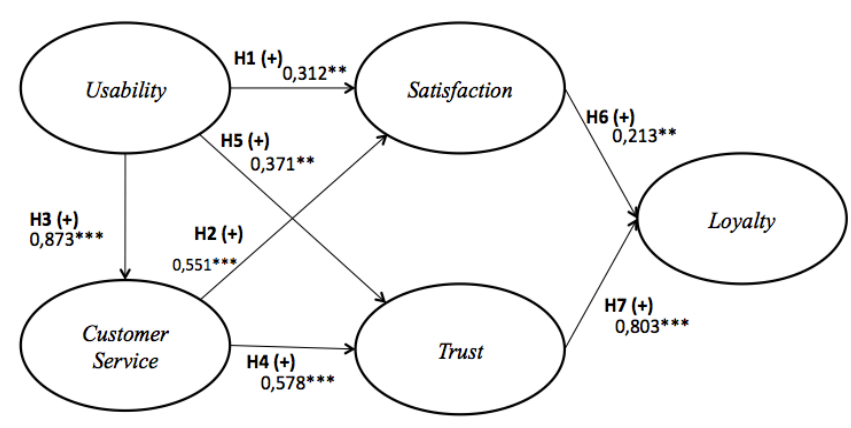

21 for Windows program are supported. Here is the explanation: There is a positive influence of usability, customer service on customer satisfaction of mobile banking users in Surabaya. There is a positive influence of usability on customer service of mobile banking users in Surabaya. There is a positive effect of customer service on trust of mobile banking users in Surabaya. There is a positive influence of usability to trust of mobile banking users in Surabaya. There is a positive influence of satisfaction on loyalty of mobile banking users in Surabaya. There is a positive influence of trust on loyalty of mobile banking users in Surabaya.

From the research results, it is known that trust has the biggest influence on loyalty of mobile banking user. Therefore, banking companies must continue to

Figure 1. Overall Structural Model.

The result of this study indicates that usability has a positive influence on customer satisfaction of mobile banking user in Surabaya. Thereby, it can be said that better display or interface and easier use of mobile banking will increase customer satisfaction.

Customer service positively affects customer satisfaction of mobile banking user in Surabaya. This signifies that better customer service of mobile banking provider will also increase customer satisfaction.

Usability has a positive influence on customer service of mobile banking user in Surabaya. Thus, it can be said that better display or interface and easier use of mobile banking will be an antecedent to customer service.

The result shows that customer service has a positive influence on trust of mobile banking users in Surabaya. It can be concluded that the better the customer service, the higher the level of trust given by customers to mobile banking services would be.

Usability has a positive effect on trust of mobile banking users in Surabaya. It can be concluded that the better the display or interface and the more user friendly the mobile banking, the higher the level of trust given by the customer would be.

Customer satisfaction variable positively influences the loyalty of mobile banking users in Surabaya. This signifies that the greater the level of customer satisfaction, the greater the loyalty level of mobile banking users in Surabaya would be. The result shows that trust positively affects loyalty of mobile banking users in Surabaya. Thus, it can be said that the greater the level of customer confidence in mobile banking, the higher the customer loyalty in using mobile banking would be.

\section{CONCLUSION}

Based on the research and test results, it can be concluded that all 7 hypotheses that have been tested using Structural Equation Modeling (SEM) with AMOS always keeping up with the needs of current customers such as the addition of The Indonesian National Health Insurance (BPJS) payment transaction feature and water utilities (PDAM) which is currently limited to mobile banking services.

Mobile banking service providers must also provide reliable customer service and able to solve the problems experienced by customers in a correct and prompt manner.

This can be achieved through regular employee training on product knowledge of existing services on mobile banking and how to deal with customers who complain or need assistance appropriately.

In addition, mobile banking service providers also need to conduct further research to the active mobile banking users on what should be improved in terms of application display also difficulties experienced when using the service. Through the following things, it is expected to create an overall customer satisfaction that leads to increased customer loyalty in using mobile banking.

\section{REFERENCES}

Anderson, E.W., Fornell, C., \& Lehmann, D.R. 1994. Customer satisfaction, market share, and profitability: findings from Sweden. Journal of Marketing 58(3): 53-66.

Darmasetiawan, N.K., M.S. Idrus, E.A. Troena, \& U. Salim. 2013. Application concept of social capital theory and social exchange theory on organizational trust, willingness to share, membership involvement, and knowledge obtaining dimensions in industry cluster. International Journal of Business and Behavioral Sciences 3(2): 15-33.

Floh, A. \& Treiblmaier, H. 2006. What keeps the e-banking customer loyal? a multigroup analysis of the moderating role of consumer characteristics on e-loyalty in the financial service industry. Journal of Electronic Commerce Research 7(2): 97-110.

Gangguli, S. \& Roy, S.K. 2011. Generic technology-based service quality dimensions in banking. International Journal of Bank Marketing 2011: 168-189.

Hallowell, R. 1996. The relationships of customer satisfaction, customer loyalty, and profitability: an empirical study. International Journal of Service Industry Management 7(4): 27- 
Lee, K.C. \& Chung, N. 2009. Understanding factors affecting trust in and satisfaction with mobile banking in Korea: a modified DeLone and McLean's model perspective. Interacting with Computers 21(5): 385-392.

Lin, H.-H. \& Wang, Y.S. 2006. An examination of the determinants of customer loyalty in mobile commerce contexts. Information \& Management 43(3): 271-282.

Luo, X., Li, H., Zhang, J., \& Shim, J.P. 2010. Examining multidimensional trust and multi- faceted risk in initial acceptance of emerging technologies: an empirical study of mobile banking services. Decision Support Systems 49(2): 222-234.

Maharsi, S. \& Fenny. 2006. Analisa faktor-faktor yang mempengaruhi kepercayaan dan pengaruh kepercayaan terhadap loyalitas penguna internet banking d Surabaya. (Unpublished thesis). Universitas Kristen Petra. Surabaya.

Mukherjee, A. \& Nath, P. 2003. A model of trust in online relationship banking. International Journal of Bank Marketing 21: 5-15.

O’Malley, L. \& Tynan, C. 2000. Relationship marketing in consumer markets - rhetoric or reality? European Journal of Marketing 34(7): 797-815.

Schaupp, L.C. \& Belanger, F. 2005. A conjoint analysis online consumer satisfaction. Journal of Electric Commerce Research 6: 95-111

Thakur, R.. 2014. What keeps mobile banking customers loyal? International Journal of Bank Marketing 32(Iss 7): 628-646.

Yeh, Y.S., \& Li, Y.-M. 2009. Building trust in m-commerce: contributions from quality and satisfaction. Online Information Review 33(6): 1066-1086.

Yoon, S.J. \& Kim, J.H. 2000. An empirical validation of a loyalty model based on expectation disconfirmation. Journal of Consumer Marketing 17(2): 120-136.

Zhou, T. 2012. Examining mobile banking user adoption from the perspectives of trust and flow experience. Information Technology and Management 13(1): 27-37. 